\title{
ボーリング孔を利用せる非定常流透水試験法について
}

\author{
正員小田

\section{ON THE PERMEABILITY TEST OF UNSTEADY FLOW UTILIZING THE BORING HOLE}

英

By Eiichi Oda, C.E. Member

\begin{abstract}
Synopsis : In this paper, the author introduces the calculating formulas for the coefficient of permeability by the permeability test of unsteady flow utilizing the boring hole. From the observed data of the rise and fall of water level with time in the boring casing pipe pouring water into this pipe and stopping this pouring after steady flow of aquifer respectively, the coefficient of permeability is determined by the graphical and theoretical analysis introduced by heat conductive formula.

要 旨 透水性地盤の地質調査のため ボーリングをして透水係数を知りたい場合，このボーリング孔 とケーシング パイプを打込み，これと注水したりまたは定常流状態のとき注水を停止してケーシング パ イプ内の水位の時間的変化の観測より透水係数を求める理論を研究した。また実験によりこの理論のう らづけを行つた結果につき述べる。
\end{abstract}

\section{1. 緒言}

ボーリング孔イケーシングパイプを打込み，これを利用してこの管に一定水量で注水して，このときの注水量， 水位上昇の時間的関係すなわち非定常流状態の水位変動を測定する。また一定水位になつたとき，すなわち定常 流状態より急に注水を停止したときの 水位降下の非定常流状態の水位変動の測定より 地盤の透水係数を測定しょ ろとする。

ただし，この試験法はボーリング底が地下水面より下にある場合に適用できるものである。この注水のときの 水位の時間的変動の椂相は井戸の揚水試験の様相と逆になり，揚水の非定常流状態はこの場合注水の非定常流状 態にあたり，また井戸試験の回復法がこの場合の注水停止の 非定常流状態にあたるとみなされる。ゆえに用いる 理論式は井戸の非定常流理論を用いる。井戸の汲下量がこの場合では水位上昇量となり，井戸の回復法に抽ける 水位回復量はこの場合では定常流状態の水位より 注水停止後の降下量にあてはまると考峒しととである。 そこでいま半球形多孔底面を有する井戸で側壁にストレーナのない井戸の非定常流理論とついて述べる。ボーリ

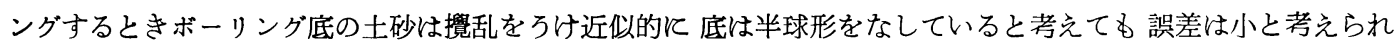
るゆえに, 半球形多孔底面を有する井戸を考光たわけである。ストレーナのある井戸の非定常流理論に颃いて, ある点の水位降下量と井戸中心よりその点までの距離 抽よび時間との関係は円壔座標による熱伝導の式となり, これてついては C.E. Jacob ${ }^{1}$ 扰よび Russell H. Broun ${ }^{2}$ の研究がある。半球形多孔底面を有する井戸の非定常流 理論は球座標とよる熱伝導の式となり，この解より直線解法と典型曲線解法とを導き出し透水係数を求める理論 につき説明し，室内の模型実験によりこの理論の妥当性につき検討する。

\section{2. 半球形多孔底面を有する井戸の非定常流理論}

被圧地下水でその帯水層が地表面よりある深さより以下無限の下方に搪がつて あるとき，その上の不透水層を井戸が貫き，図一1 亿示すごとくこの不透水層の 下端汗半球形の多孔井戸底を有する構造とするとき, 井戸の揚水時の帯水層中の 地下水の非定常流の問題を取りあつかう。Forchheimer によれば不透水層なき 浅井の場合でも近似的飞被压地下水の井戸の理論を適用できる。

原圧力線を $\mathrm{OA}$, 井戸中飞招ける汲下量 $s_{0}$ 飞対する涌出量を $Q$, 揚水時の降 下せる圧力線を $\mathrm{CD}$, 井戸の半径を $r_{0}$, 井戸の底は $\mathrm{O}^{\prime}$ を中心とする半径 $r_{0}$ の 半球形多孔底面とする。

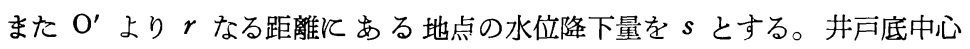

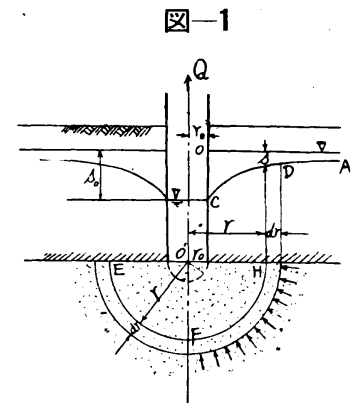

* 徳島大学教授, 工学部土木工学教室 
$\mathrm{O}^{\prime}$ を共有する半球形球殼の内側の半径を $r$, 外側の半径を $r+d r$ とする。連続の条件よりこの球殼より流れ出る 水量は球殼の中の水の容積の一定時間中の減少量に等しい。球殼の中の水の容積を $V_{w}$, 帯水層の空ゲキ率を $n$, 水の圧縮率を $\beta$, 水の単位容積当りの重量を $r$, 時間を $t$ とすれば

$$
V_{w}=2 \pi r^{2} n d r
$$

この容積の時間的減少は次式となる。

$$
\frac{\partial V_{w}}{\partial t}=2 \pi r^{2} n \beta d r \cdot \frac{\partial(\gamma s)}{\partial t}
$$

压力が減少して水が膨脤すると弾性的に圧縮される帯水層の圧縮性を考兄て $\beta$ の代りに見掛圧縮率 $\beta^{\prime}$ を用いる。 しからば上式は次式となる。

$$
\frac{\partial V_{w}}{\partial t}=2 \pi r^{2} n \beta^{\prime} \gamma d r \cdot \frac{\partial s}{\partial t}
$$

水の見掛圧縮率 $\beta^{\prime}$ は水と土との圧縮率に関係し

$$
\beta^{\prime}=\beta+\frac{\alpha}{n}
$$

となる。ただし $\alpha$ は帯水層の圧縮率である。すなわち帯水㟄の土の中の圧縮力の鉛直成分の単位増加に対する帯 水層の厚さの相対的な減少量である。

半球形球壳の内面よりの流出量は $-2 \pi r^{2} k\left(\frac{\partial s}{\partial r}\right)$ である。ただし $k$ は帯水層の透水係数である。また半球形 球殼の外側の面より共戸底中心向い流出する水量は

$$
2 \pi(\boldsymbol{r}+\boldsymbol{d} r)^{2} k\left(\frac{\partial s}{\partial r}+\frac{\partial^{2} s}{\partial r^{2}} d r\right)
$$

である。この両者の和は水の半球形球殼の容積の時間的減少飞等しい。高次の微係数を無視して計算すれば

$$
2 \pi k\left(r^{2} \frac{\partial^{2} s}{\partial r^{2}} d r+2 r \frac{\partial s}{\partial r} d r\right)=2 \pi r^{2} n \beta^{\prime} r d r \cdot \frac{\partial s}{\partial t}
$$

上式を $2 \pi r^{2} d r$ で割り

$$
n \beta^{\prime} \gamma=U \text {. }
$$

と扔けば次式をろる。

と招けば

$$
\begin{aligned}
& \frac{\partial^{2} s}{\partial r^{2}}+\frac{2}{r} \frac{\partial s}{\partial r}=\frac{U}{k} \frac{\partial s}{\partial t} \\
& \kappa^{2}=\frac{k}{U} \quad \text { すなわち } \quad \kappa=\sqrt{\frac{k}{U}}
\end{aligned}
$$

$$
\kappa^{2}\left\{\frac{\partial^{2} s}{\partial r^{2}}+\frac{2}{r} \frac{\partial s}{\partial r}\right\}=\frac{\partial s}{\partial t}
$$

となる。これは球座標による熱伝導の式である。

この場合上の微分方程式を解くのに必要な条件は次のようになる。

初期条件 $t=0$ のとき $s=0$

境界条件 $r=\infty$ のとき $s=0$

$$
t>0 \text { のとき } \underset{r \rightarrow 0}{L}\left(r^{2} \frac{\partial s}{\partial r}\right)=-\frac{Q}{2 \pi k}^{3)}
$$

(5) 式に挍いて

$$
s=\frac{v}{r} \quad \text { すなわち } v=r s
$$

とすれば

$$
\kappa^{2} \frac{\partial^{2} v}{\partial r^{2}}=\frac{\partial v}{\partial t}
$$

となる。これと関連して前の初期条件，境界条件は次のようになる。

(i) 初期条件 - $t=0$ のとき $v=0$

(ii) 境界条件 $\quad r=\infty$ のとき $\underset{r \rightarrow \infty}{L} \frac{\partial v}{\partial r}=0$ 抢よび $\underset{r \rightarrow \infty}{L} \underset{v=0}{v}$

(iii）境界条件 $\quad t>0$ のとき $\underset{r \rightarrow 0}{L} v=\frac{Q}{2 \pi k}$ 
いま

$$
V(\xi, t)=\sqrt{\frac{2}{\pi}} \int_{0}^{\infty} v(r, t) \sin (\xi r) d r
$$

とする。これは $v(r, t)$ の Fourier sine transform である。次の演算において境界条件（ii）抢よび（iii）を用 いて計算すれば

$$
\sqrt{\frac{2}{\pi}} \int_{0}^{\infty} \frac{\partial^{2} v}{\partial r^{2}} \sin (\xi r) d r=\sqrt{\frac{2}{\pi}} \xi \frac{Q}{2 \pi k}-\xi^{2} V(\xi, t)
$$

となることを利用して（7）式に次の演算をなす。

$$
\kappa^{2} \sqrt{\frac{2}{\pi}} \int_{0}^{\infty} \frac{\partial^{2} v}{\partial r^{2}} \sin (\xi r) d r=\frac{\partial}{\partial t}\left\{\sqrt{\frac{2}{\pi}} \int_{0}^{\infty} v \sin (\xi r) d r\right\}
$$

これより

$$
\frac{\partial V}{\partial t}+\xi^{2} \kappa^{2} V=\sqrt{\frac{2}{\pi}} \xi \kappa^{2} \frac{Q}{2 \pi k}
$$

がえられる。(9) 式を解けば

$$
V=\sqrt{\frac{2}{\pi}} \frac{Q}{2 \pi k}\left\{\frac{1}{\xi}+C e^{-\xi^{2} \kappa^{2} t}\right\}
$$

となる。ただし $C$ は積分常数である。初期条件 (i) より (8) 式を用いて

$$
\begin{aligned}
& V(\xi, 0)=0 \text { より } C=-\frac{1}{\xi} \text { となり } \\
& V(\xi, t)=\sqrt{\frac{2}{\pi}} \frac{Q}{2 \pi k}\left\{\frac{1-\mathrm{e}^{-\xi^{2} \kappa^{2} t}}{\xi}\right\} .
\end{aligned}
$$

なる解がえられる。Fourier sine transform の定理より

$$
v(r, t)=\sqrt{\frac{2}{\pi}} \int_{0}^{\infty} V(\xi, t) \sin (\xi r) d \xi=\frac{2}{\pi}\left[\frac{Q}{2 \pi k} \int_{0}^{\infty}\left\{\frac{1-\mathrm{e}^{-\xi^{2} \kappa^{2} t}}{\xi}\right\} \sin (\xi r) d \xi\right]
$$

これより

$$
v(r, t)=\frac{Q}{2 \pi k}-\frac{2}{\sqrt{\pi}} \frac{Q}{2 \pi k} \int_{0}^{\frac{r}{2 \kappa t^{1 / 2}}} \mathrm{e}^{-u 2} d u
$$

(6) 式に（11）式を代入して

$$
s(r, t)=\frac{Q}{2 \pi k r}\left\{1-\frac{2}{\sqrt{\pi}} \int_{0}^{\frac{r}{2 \kappa t^{1 / 2}}} \mathrm{e}^{-u 2} d u\right\}
$$

となり，(5) 式の解がえられた。

\section{3. 直線解法}

(12) 式机招いて

$$
\frac{r}{2 \kappa t^{1 / 2}}=\alpha
$$

として, $\int_{0}^{\alpha} \mathrm{e}^{-\mu^{2}} d u$ を無限級数の項に展開すれば, (12) 式は

$$
s(r, t)=\frac{Q}{2 \pi k r}-\frac{Q}{\pi \sqrt{\pi} k r}\left[\alpha-\frac{\alpha^{3}}{3}+\frac{\alpha^{5}}{5 \cdot 2 !}-\frac{\alpha^{7}}{7 \cdot 3 !}+\cdots \cdots\right]
$$

となり，tが大になるとき， $\alpha^{3}, \alpha^{5}, \alpha^{7} \cdots$ は $\alpha$ と比し僅少なるゆえ無視できて, 上式は (13) 式を用いて次式とな る。

$$
s(r, t)=\frac{Q}{2 \pi k}\left(\frac{1}{r}-\frac{1}{\sqrt{\pi}} \frac{1}{\pi t^{1 / 2}}\right)
$$

(14) 式の両辺に $t^{1 / 2}$ を乗じて

$$
\begin{aligned}
& s t^{1 / 2}=Y \text { 抢よび } \frac{t^{1 / 2}}{r}=X \text { として } \\
& Y=\frac{Q}{2 \pi k}\left(X-\frac{1}{\sqrt{\pi}} \frac{1}{\kappa}\right) \ldots \ldots \ldots \ldots \ldots \ldots . .
\end{aligned}
$$

となる。 $X$ 軸を横軸に $Y$ 軸を縦軸にとり, この座標軸とより $s$ と $t$ との測定値より計算して, $X$ と $Y$ との関: 係を示す曲線を引くとき，この曲線が $t$ が大となるにつれて直線となる部分に注目して，この直線の勾配 $\left(\frac{d Y}{d X}\right)_{s}$ 
を求め (15) 式の形よりして

$$
k=\frac{Q}{2 \pi} \cdot \frac{1}{\left(\frac{d Y}{d X}\right)_{s t}}
$$

によつて透水係数 $k$ の值を求めることができる。な括この直線が $X$ 軸と交わる点の $X$ の值を $X_{0}$ とすれば

$$
\kappa=\frac{1}{\sqrt{\pi} X_{0}}
$$

によつて の值を求めることができる。

\section{4. 典型曲線解法}

いま error function を次のようにおく

$$
\Phi(u)=\frac{2}{\sqrt{\pi}} \int_{0}^{u} \mathrm{e}^{-u^{2}} d u
$$

ただし, 上式汸いて

$$
u=\frac{r}{2 \kappa t^{1 / 2}}
$$

と拓くとき，(12) 式㰡次のようになる。

$$
1-\Phi(u)=\frac{2 \pi k}{Q} \cdot s r
$$

(18) 式と（19）式との両辺の対数をとれば

$$
\begin{aligned}
& \log u=\log \left(\frac{1}{2 \kappa}\right)+\log \left(\frac{r}{t^{1 / 2}}\right) \cdots \cdots \cdots \cdots \\
& \log \{1-\Phi(u)\}=\log \left(\frac{\dot{2} \pi k}{Q}\right)+\log (\mathrm{s} r)
\end{aligned}
$$

となる。(20) 式の $\log \left(\frac{1}{2 \kappa}\right)$ と $\log \left(\frac{2 \pi k}{Q}\right)$ とは恒量であるから, $u$ と 1 -の(u) との関係を示す典型曲線と $\frac{r}{t^{1 / 2}}$ と $s r$ との関係を示す曲線とを両対数紙上飞画くと，これ等の曲線はその形が同一となるはずである。別に 発表されている $\Phi(u)$ の数值表より 1- $(u)$ を求め, この値と試験井戸で集められる水位変動の資料とを利用し て，これ等の曲線を両対数紙上に求める。この二つの両対数紙上の曲線を良好な一致点 (match point) がえられ るまで座標軸を平行に保つて重ね合わせる。一致点が見つかつたらそれに対応する $1-\Phi(u), u, s r, \frac{r}{t^{1 / 2}}$ の值 を読みとり，これ等の値を（18）式と（19）式とに代入して，それぞれより $ィ$ とを求めることができる。すな わち,

$$
\begin{aligned}
& k=\{1-\Phi(u)\} \frac{Q}{2 \pi s r} \\
& \kappa=\frac{r}{2 u t^{1 / 2}} \ldots \ldots \ldots \ldots
\end{aligned}
$$

となる。な招 1-の(u) の值を 表一1 と示す。

\section{5. 実験への適用およひ実験資料の解析}

実験装置としては 写真一1 扎よび 図一2 亿示すように 高さ $100 \mathrm{~cm}$, 直佳 $55 \mathrm{~cm}$ のドラム缶の下底より $40 \mathrm{~cm}$ 上 そ鉄製有孔上底をとりつけ，この上底に粗目の布をしき， この上に吉野川砂を $50 \mathrm{~cm}$ の厚さに均一につめる。ドラム 缶の上縁に一定水位を保たしめるため溢流用ノッチをつけ る。この砂の中央にガラス主管を挿入し，つめた砂を襣乱 しないょうルガラス主管内の砂を排除しながら所定の根入 深さまで挿入したならば，底を半球形になるように砂を取 る。しかる後 図一2 の $A$ の孔のゴム栓をとり水道水を入 れ, 除々に水位を砂の中にあげ溢流用ノッチより溢流さし

写真-1 実験装置

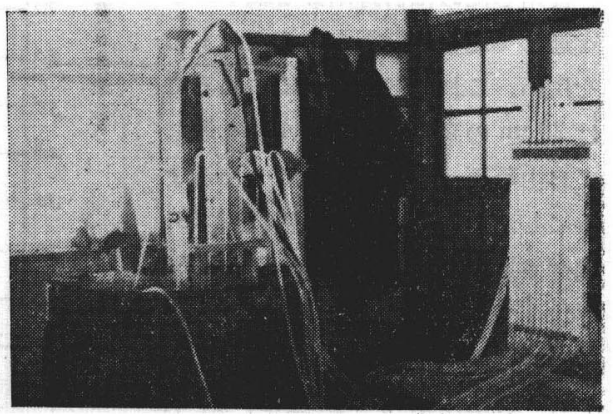

数日間放置して $A$ のの栓をなす。次に注水用調節水槽よりサイフォンによりガラス主管に注入し，溢流水面捻 
表-1 1 Ф(u) の值

\begin{tabular}{c|c||c|c||c|c|c||c|c||c|c|c}
\hline$u$ & $1-\Phi(u)$ & $u$ & $1-\Phi(u)$ & $u$ & $1-\Phi(u)$ & $u$ & $1-\Phi(u)$ & $u$ & $1-\Phi(u)$ \\
\hline 0.000 & 1.0000 & 0.040 & 0.9549 & 0.450 & 0.5245 & 1.100 & 0.1198 & 2.000 & 0.0047 \\
0.001 & 0.9989 & 0.050 & 0.9436 & 0.500 & 0.4795 & 1.150 & 0.1039 & 2.100 & 0.0030 \\
0.002 & 0.9977 & 0.060 & 0.9324 & 0.550 & 0.4367 & 1.200 & 0.0897 & 2.200 & 0.0019 \\
0.003 & 0.9966 & 0.070 & 0.9211 & 0.600 & 0.3961 & 1.250 & 0.0771 & 2.300 & 0.0011 \\
0.004 & 0.9955 & 0.080 & 0.9099 & 0.650 & 0.3580 & 1.300 & 0.0660 & 2.400 & 0.0007 \\
0.005 & 0.9944 & 0.090 & 0.8987 & 0.700 & 0.3222 & 1.350 & 0.0562 & 2.500 & 0.0004 \\
0.006 & 0.9932 & 0.100 & 0.8875 & 0.750 & 0.2888 & 1.400 & 0.0477 & 2.600 & 0.0002 \\
0.007 & 0.9921 & 0.150 & 0.8320 & 0.800 & 0.2579 & 1.450 & 0.0403 & 2.700 & 0.0001 \\
0.008 & 0.9910 & 0.200 & 0.7773 & 0.850 & 0.2293 & 1.500 & 0.0339 & 2.800 & 0.0001 \\
0.009 & 0.9898 & 0.250 & 0.7237 & 0.900 & 0.2030 & 1.600 & 0.0236 & 2.900 & 0.0000 \\
0.010 & 0.9887 & 0.300 & 0.6714 & 0.950 & 0.1791 & 1.700 & 0.0172 & 3.000 & 0.0000 \\
0.020 & 0.9774 & 0.350 & 0.6206 & 1.000 & 0.1573 & 1.800 & 0.0109 & & \\
0.030 & 0.9662 & 0.400 & 0.5716 & 1.050 & 0.1376 & 1.900 & 0.0072 & &
\end{tabular}

図一2ガラス主管による非定常流透水実験装置

図一3 定水頭透水実験装置

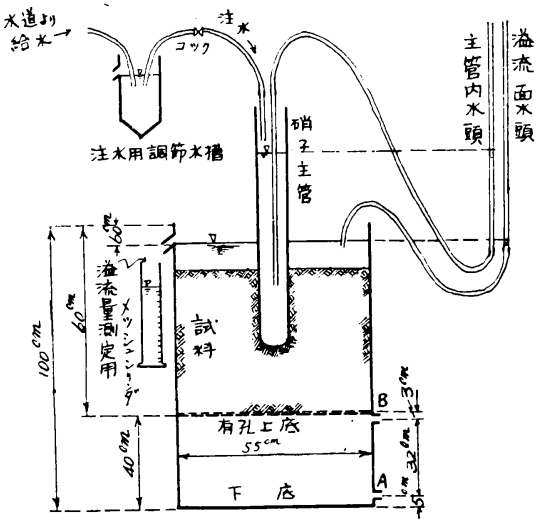

よびガラス主管内の水をサイフォンによりピエゾメータと導 き水位を測定し, 溢流用ノッチより流出する水量を測り注水 量とする。このような装置により一定注水量のとき定常流状 態となりガラス主管内の水頭が一定高さとなつてから注水停

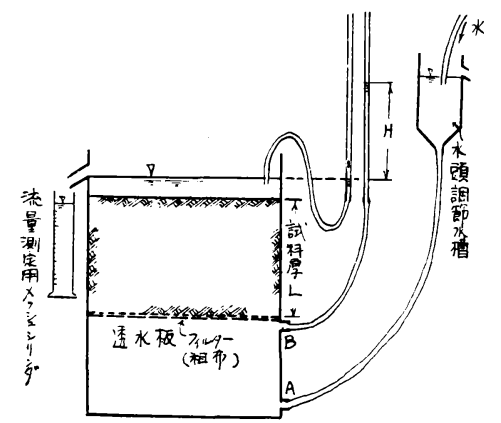

図一4 ピエゾ管

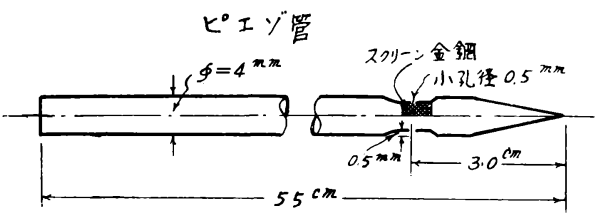

止すると, ガラス主管内の水位が時間の経つと従つて降下する。またこの水位が溢流水面と同じになつたとき一 定水量で注水すれば時間的に水位が上昇する。このような水位の時間的変動を測定し 非定常流透水実験をなして 透水係数を求めるが, 他の方法でこの砂の透水係数を測定するために 図一-3 に示すようにドラム畋自体が定水頭

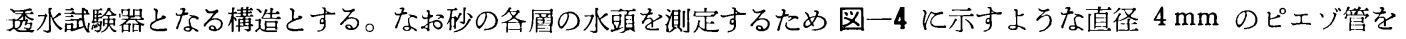
所定の深さまで挿入しサイフォンに 図一5 実験用砂の粒径加積曲線 よりピエゾメータに連結して定水頭 透水試験飞打ける水頭を測定して各 風の透水係数を求める。

使用した砂は吉野川砂を網フルイ を通して比較的粒径をそろえたもの を用い，これをドラム缶とつめるに 社 $20 \mathrm{~cm}$ の高さより網フルイを通し て自由落下せしめて均一につまるよ ろにした。この砂の真比重は 2.69 , 間ゲキ比は 0.710 , 乾燥密度は 1.56 $\mathbf{g} / \mathrm{cm}^{3}$ であつた。粒度分布は図一5 に示すごとくで $D_{10}=0.30, D_{60}=$ 0.57 , 均等係数 $\mu=\frac{D_{60}}{D_{10}}=1.90$ で

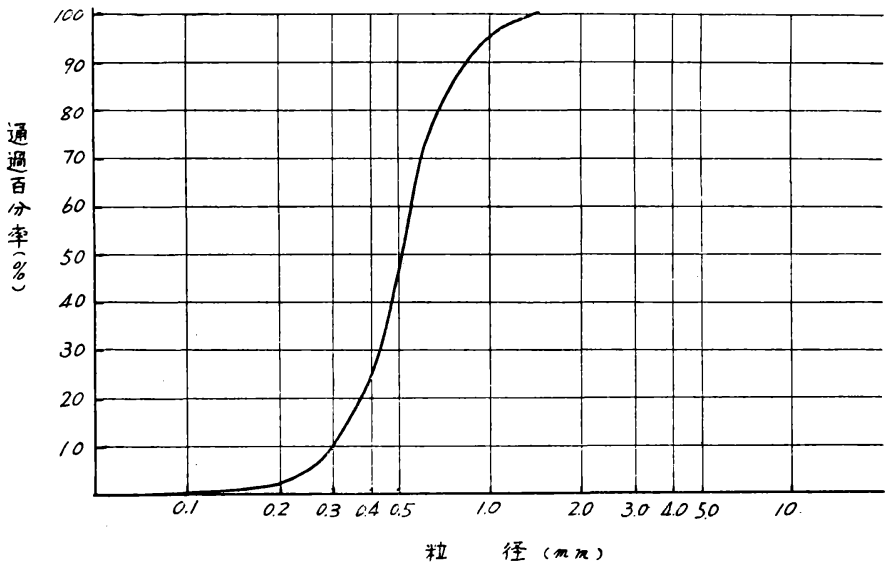


あつた。

直径 $4.3 \mathrm{~cm}$ のガラス主管の根入 れ $15.0 \mathrm{~cm}$ 㲹して非定常流透水実 験を行つた $s \sim t$ の測定結果を図一 6 亿示す。この実験に於て注水量 $Q$ $=12.7 \mathrm{~cm}^{3} / \mathrm{sec}, \quad$ ガラス主管の半径 は $2.15 \mathrm{~cm}$ なるゆえ $r=2.15 \mathrm{~cm}$ と とり, $s$ はガラス主管の水位であり, 注水試験のときは溢流水面より測つ た水頭高さであり, 注水停止試験の ときは定常流状態のときのガラス主 管内の水頭高よりの降下量である。 注水停止試験のとき計算使いる $Q$ の值としては定常流状態のときの注 水量を用いることは井戸の回復法の 場合と同じ考方方によるゆえに, $Q=12.7 \mathrm{~cm}^{3} / \mathrm{sec}$ とすることができ る。測定時の水温 $T=9.0^{\circ} \mathrm{C}$ であつ 図一6 $Q=12.7 \mathrm{~cm}^{3} / \mathrm{sec}$, ガラス主管半径 $r=2.15 \mathrm{~cm}$, 根入れ $15.0 \mathrm{~cm}$ のときの非定常流透水試験の $\boldsymbol{s} \sim \boldsymbol{t}$ 実測值およひ理論值

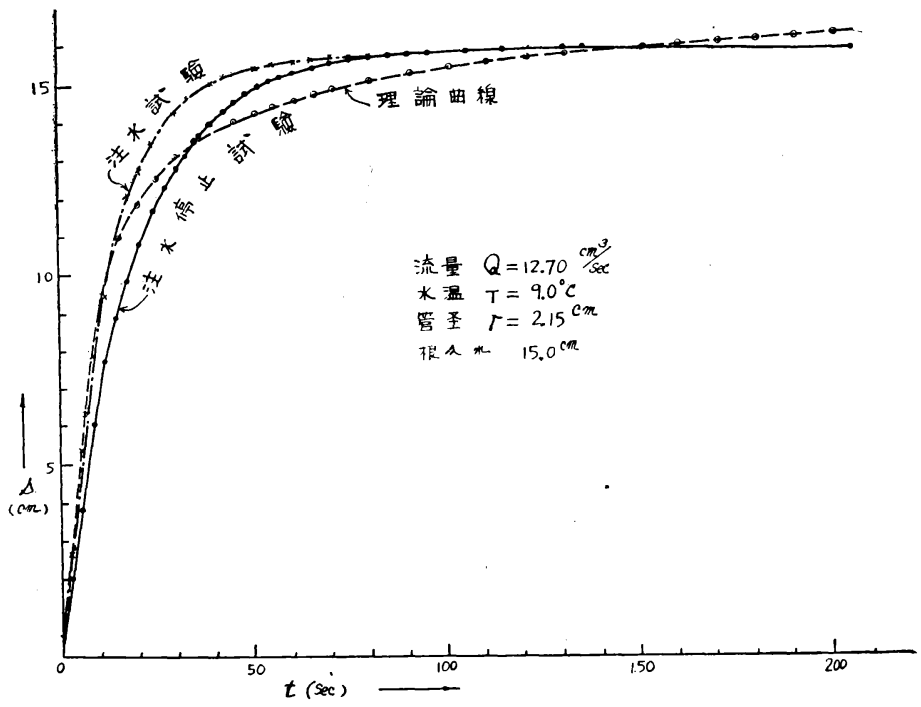
た。図一6 の測定值より直線解法のための $X, Y$ 值を計算して図示したものが図一7であり, この $X, Y$ 曲線が $t$ の大となるに従つて直線となることを示している。この直線の傾斜は $\left(\frac{d Y}{d X}\right)_{s t}=41 \mathrm{~cm}^{2}$ となり, (16) 式より $k=0.0493 \mathrm{~cm} / \mathrm{sec}$ となる。この直線の $X$ 軸との交点の $X_{0}=0.63 \mathrm{~cm}^{-1} \mathrm{sec}^{1 / 2}$ の值より (17) 式を用いて $\kappa=0.898$ : $\mathrm{cm} / \mathrm{sec}^{1 / 2}$ となる。井戸の揚水試験より透水係数を求める場合回復法を用いて計算することがあるようと, この場 合の $s \sim t$ の值としては注水停止試験のときの測定值を用いる。次の典型曲線解法に扔いても同じこである。図一 6 の測定值より典型曲線解法のため $s r, r / t^{1 / 2}$ の值を計算して両対数紙上飞画いた実験曲線と表一1 より $1-\Phi(u)$ と $u$ の值を両対数紙上飞画いた典型曲線を図一8 亿示すように座標軸平行になるように重ね合わせる。

\section{図一 $7 Q=12.7 \mathrm{~cm}^{3} / \mathrm{sec}$, ガラス主管半径 $r=2.15 \mathrm{~cm}$,} 根入れ $15 \mathrm{~cm}$ のときの直線解法

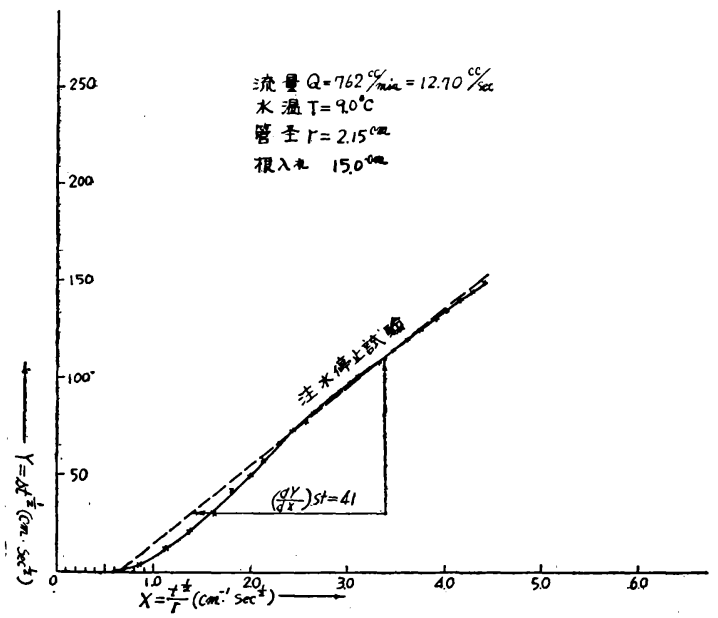

図一8 $Q=12.7 \mathrm{~cm}^{3} / \mathrm{sec}$, ガラス主管半径 $r=2.15 \mathrm{~cm}$, 根入れ $15 \mathrm{~cm}$ のとき の典型曲線解法

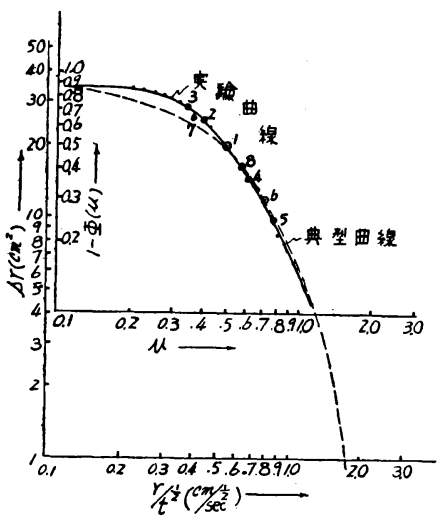

図一8の match point 1 の座標の值として $1-\Phi(u)=0.50, u=0.48, s r=19.6 \mathrm{~cm}^{2}, \quad r / t^{1 / 2}=0.54 \mathrm{~cm} / \mathrm{sec}^{1 / z}$

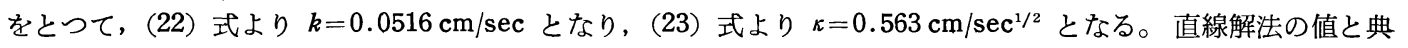
型曲線解法の值との平均值をとつて $k=0.0505 \mathrm{~cm} / \mathrm{sec}, k=0.731 \mathrm{~cm} / \mathrm{sec}^{1 / 2}$ として (19) 式に执いて 表一1 を用 いて $s$ を求めれば $s \sim t$ の関係を示す理論值がえられ，これは図一6 と理論曲線として示すと，実測曲線と近似 的嵓つている。

図一9 はガラス主管の直径 $3.76 \mathrm{~cm}$ すなわち半径 $r=1.88 \mathrm{~cm}$ のものの根入 $20 \mathrm{~cm}$ の場合の $Q=14.55 \mathrm{~cm}^{3} /$ $\mathrm{sec}, 11.23 \mathrm{~cm}^{3} / \mathrm{sec}, 8.72 \mathrm{~cm}^{3} / \mathrm{sec}$ のそれぞれに対する注水停止試験に括ける $s \sim t$ の実測值を曲線に示したもの 
で, 水温は $13^{\circ} \mathrm{C}$ であつた。 $Q=14.55 \mathrm{~cm}^{3} / \mathrm{sec}$ のときの実測值より 図一10 と示すような直線 解法によつて $\left(\frac{d Y}{d X}\right)_{s t}=39 \mathrm{~cm}^{2}, X_{0}=0.47 \mathrm{~cm}^{-1}$ $\sec ^{1 / 2}$ の值よりそれぞれ $k=0.0595 \mathrm{~cm} / \mathrm{sec}$ ， $\kappa=1.200 \mathrm{~cm} / \mathrm{sec}^{1 / 2}$ となる。また図一11飞示す ような典型曲線解法によつて match point $\mathrm{A}$ の值より $1-\Phi(u)=0.50, \mu=0.48, s r=22 \mathrm{~cm}^{2}$, $r / t^{1 / 2}=0.60 \mathrm{~cm} / \mathrm{sec}^{1 / 2}$ をえて $k=0.0526 \mathrm{~cm} / \mathrm{sec}$ $\kappa=0.626 \mathrm{~cm} / \mathrm{sec}^{1 / 2}$ となる。

直線解法の值と典型曲線解法の值との平均值 をとつて $k=0.0561 \mathrm{~cm} / \mathrm{sec}, \kappa=0.913 \mathrm{~cm} / \mathrm{sec}^{1 / 2}$ となり, この值を用いて（19）式により $s \sim t$ の理論值を計算し図示したものが図一9 の理論 曲線で $Q=14.55 \mathrm{~cm}^{3} / \mathrm{sec}, 11.23 \mathrm{~cm}^{3} / \mathrm{sec}, 8.72$

図一10 $Q=14.55 \mathrm{~cm}^{3} / \mathrm{sec}$, ガラス主管半径 $r=1.88$ $\mathrm{cm}$, 根入れ $20 \mathrm{~cm}$ のときの直線解法

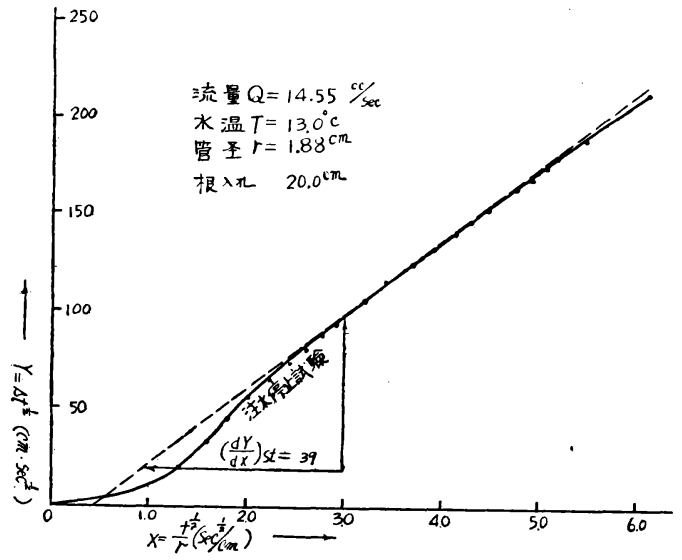

図一12 $Q=14.55 \mathrm{~cm}^{3} / \mathrm{sec}$, ガラス主管半径 $r_{0}=1.88 \mathrm{~cm}$, 根入れ $20 \mathrm{~cm}$ のとき $k=0.0561 \mathrm{~cm} / \mathrm{sec}, \quad x=0.913 \mathrm{~cm} / \mathrm{sec}^{1 / 2}$ として計算した $r, s, t$ の関係を示す理論曲線

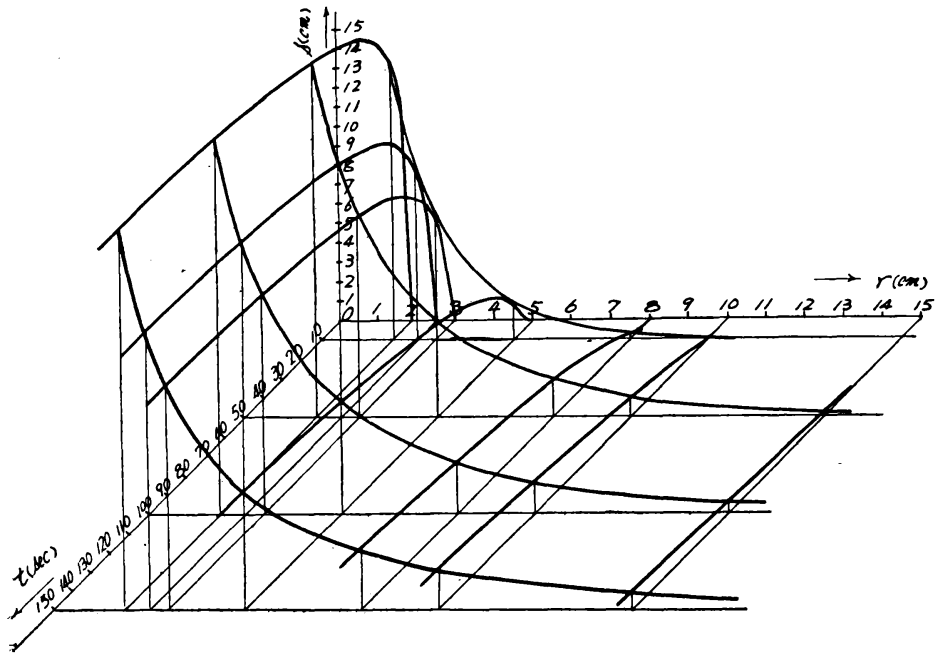

図一9 ガラス主管半径 $r=1.88 \mathrm{~cm}$, 根入れ $20 \mathrm{~cm}$ のときの 各注水量に対する非定常流透水試験における注水停止 試験の $\boldsymbol{s} \sim \boldsymbol{t}$ 実測值およひ理論值

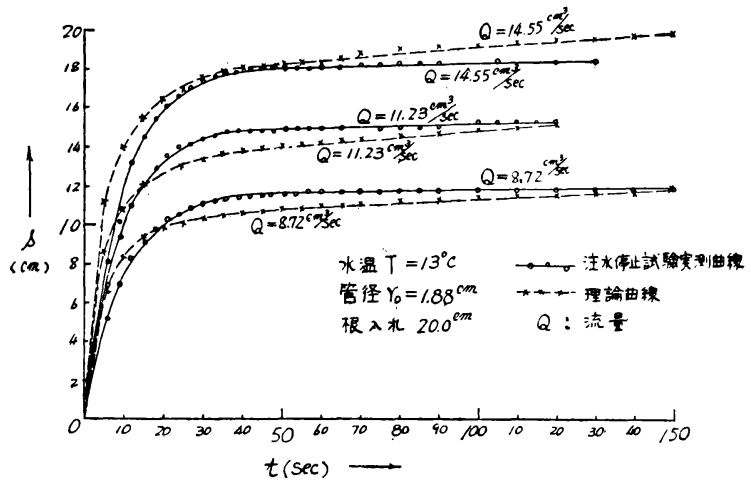

図一11 $Q=14.55 \mathrm{~cm}^{3} / \mathrm{sec}$, ガラス主管半径 $r=1.88 \mathrm{~cm}$ 根入れ $20 \mathrm{~cm}$ のときの 典型曲線解法

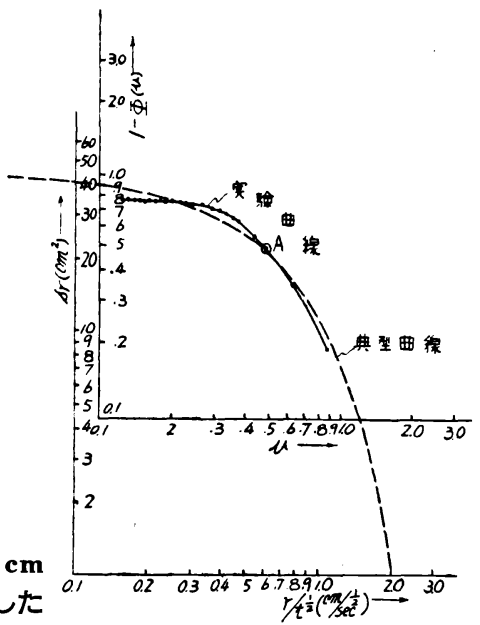

$\mathrm{cm}^{3} / \mathrm{sec}$ のそれぞれに対するす のを示し, 各注水量飞対する実 験曲線と実用的には近似してい てこの理論の罗当性を示してい る。な扰図一12 と打いて注水量 $Q=14.55 \mathrm{~cm}^{3} / \mathrm{sec}$ ，ガラス主管 半径 $r_{0}=1.88 \mathrm{~cm}$, 根入れ 20 $\mathrm{cm}$ のとき $k=0.0561 \mathrm{~cm} / \mathrm{sec}$, $\kappa=0.913 \mathrm{~cm} / \mathrm{sec}^{1 / 2}$ を用いて $r$, $t, s$ の関係を(19) 式を利用し て図示する。この図より(19)式 の熱伝導の式の特性をよく示し て打り，rが小なるほど $s \sim t$ 曲線は $t$ の小なる值で急に $s$ の 最大值行近ゔ，かつ $s$ の最大 
值は大となる。 $r$ が大となると従つて $s \sim t$ 曲線は扁平となり， $s \sim t$ 曲線に反曲点が生じてくる。また $t$ が小な るとき $s \sim r$ 曲線は実用的炕 $s=0$ となる $r$ が小であるが, $t$ が大となるに従つて $s \sim r$ 曲線の実用的に $s=0$ と なる $r$ の值が大となり, かつ各 $r$ の值に対する $s$ の值は増大しながらゆつくりと $s \sim r$ 曲線は一定の形飞近つ く。

\section{6. 実験結果の考察}

図一7 の注水停止試験の曲線の $t$ が大になると従つて直線になるが，この直線を引くときの引き方の差異によ つて, $k, \kappa$ の值にどの位の差異を拓こすかを検討してみる。図一13 そ示すようと (a-line, (b)-line, (C)-line の直 線を引いたときの值を表一2 亿示す。この場合 $Q=12.7 \mathrm{~cm}^{3} / \mathrm{sec}, r_{0}=2.15 \mathrm{~cm}$ である。 @-line は $t$ の大なると きの直線性に注目したもの, (b-line は $t$ の 小なるときと $t$ の大なるときの両方にあろ平 均的な直線を引いたもの, (C)-line は $\boldsymbol{t}$ の小 なるときの直線性に注目したすのであるが, (b-line とよつて計算したものが後述の定水 頭透水試験化よる透水係数 $k=0.0527 \mathrm{~cm} / \mathrm{sec}$ の值に近似してよいようである。

次飞典型曲線解法飞打ける match point のとり方の差異とよる $k, \kappa$ の值への影響を 検討してみる。図一B と示すように match pointを $1,2,3,4,5,6,7,8$ と種々と つてそれぞれの場合の $k, \kappa$ の值を求めると 表一3 のよろとなる。ただし $Q=12.70 \mathrm{~cm}^{3}$ $\mathrm{sec}, r_{0}=2.15 \mathrm{~cm}$ として計算する。表一3の 示すように典型曲線解法に打いて一度実験曲 線と典型曲線とを重ね合わせると，この曲線 上の match point のとり方とより $k, \pi$ の值 に大した差異はないことがわかる。

また典型曲線解法において実験曲線と典型 曲線との重悋合わせの差異泫る $k, \pi$ の值 表-2

\begin{tabular}{c|c|c|c|c}
\hline 直線の種類 & $\left(\frac{d Y}{d X}\right)_{\mathrm{st}}\left(\mathrm{cm}^{2}\right)$ & $X_{0}\left(\mathrm{~cm}^{-1} \sec ^{1 / 2}\right)$ & $\kappa(\mathrm{cm} / \mathrm{sec})$ & $\kappa\left(\mathrm{cm} / \mathrm{sec}^{1 / 2}\right)$ \\
\hline (-)-line & 37 & 0.37 & 0.0547 & 1.527 \\
(-)-line & 39 & 0.68 & 0.0520 & 0.832 \\
@-line & 49 & 1.10 & 0.0414 & 0.514 \\
\hline
\end{tabular}

\section{図一13＼cjkstart直線解法における直線の引き方の差異}

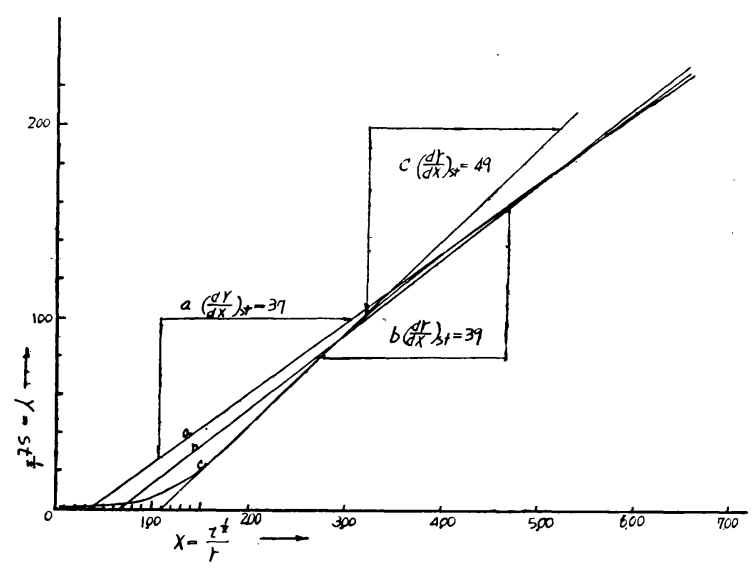
への影響を検討してみる。

表一3

\begin{tabular}{c|c|c|c|c|c|c}
\hline match point & $1-\emptyset(u)$ & $u$ & $s r\left(\mathrm{~cm}^{2}\right)$ & $r / t^{1 / 2}\left(\mathrm{~cm} / \mathrm{sec}^{1 / 2}\right)$ & $k(\mathrm{~cm} / \mathrm{sec})$ & $\kappa\left(\mathrm{cm} / \mathrm{sec}^{1 / 2}\right)$ \\
\hline 1 & 0.50 & 0.48 & 19.6 & 0.54 & 0.0516 & 0.563 \\
2 & 0.62 & 0.40 & 25.0 & 0.44 & 0.0502 & 0.550 \\
3 & 0.71 & 0.34 & 28.5 & 0.38 & 0.0504 & 0.559 \\
4 & 0.36 & 0.60 & 14.5 & 0.67 & 0.0502 & 0.558 \\
5 & 0.24 & 0.78 & 9.6 & 0.86 & 0.0506 & 0.551 \\
6 & 0.29 & 0.71 & 11.8 & 0.79 & 0.0497 & 0.556 \\
7 & 0.65 & 0.36 & 25.5 & 0.40 & 0.0516 & 0.556 \\
8 & 0.40 & 0.57 & 16.0 & 0.63 & 0.0506 & 0.553 \\
\hline
\end{tabular}

表-4

\begin{tabular}{c|c|c|c|c|c|c}
\hline $\begin{array}{c}s r \text { の最大値を合わ } \\
\text { せる1- } \boldsymbol{( u )} \text { の值 }\end{array}$ & $1-\Phi(u)$ & $u$ & $s r\left(\mathrm{~cm}^{2}\right)$ & $r / t^{1 / 2}\left(\mathrm{~cm} / \mathrm{sec}^{1 / 2}\right)$ & $k(\mathrm{~cm} / \mathrm{sec})$ & $\kappa\left(\mathrm{cm} / \mathrm{sec}^{1 / 2}\right)$ \\
\hline 1.00 & 0.40 & 0.60 & 14.0 & 0.68 & 0.0578 & 0.566 \\
0.85 & 0.50 & 0.48 & 19.6 & 0.54 & 0.0516 & 0.563 \\
0.70 & 0.48 & 0.50 & 24.0 & 0.45 & 0.0405 & 0.450 \\
\hline
\end{tabular}

実験曲線は $r / t^{1 / 2}$ の減少とつれて $s r$ は増大しながら最大值と近ずくが，この $s r$ の最大值を典型曲線の縦軸の 值 1-Ф $(u)$ の種々の值飞合わせながら実験曲線と典型曲線とを重ね合わせる。 $Q=12.7 \mathrm{~cm}^{3} / \mathrm{sec}, r=2.15 \mathrm{~cm}$ の 場合 $s r$ の最大值を $1-\Phi(u)$ の值 $1.00,0.85,0.70$ 亿合わせたものがそれぞれ 図一14, 図一8, 図一15であり, それの図の match point を $a, 1, b$ として典型曲線法により $k, \kappa$ の值を求めたるのを表一4 と示す。図一14 は $t$ の小なるときの部分と $t$ の大なるときの部分を重ね合わせたもの, 図一8 は全体的にみて重ね合わせたもの, 図一15 $t$ の小なるときの部分を重ね合わせたものであり, 図一8 の場合の $k$ の值が後述の定水頭透水試験に 
図-14 sr の最大值を 1- $\Phi(u)=1.00$ に 合わせた場合, ただし

$Q=12.70 \mathrm{~cm}^{3} / \mathrm{sec}, r=2.15 \mathrm{~cm}$

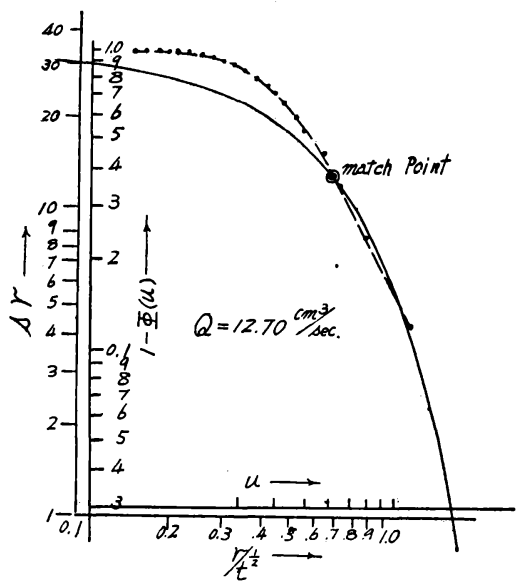

図一15 sr の最大值を 1- $\Phi(u)=0.70$ に 合わせた場合, ただし

$Q=12.70 \mathrm{~cm}^{3} / \mathrm{sec}, r=2.15 \mathrm{~cm}$

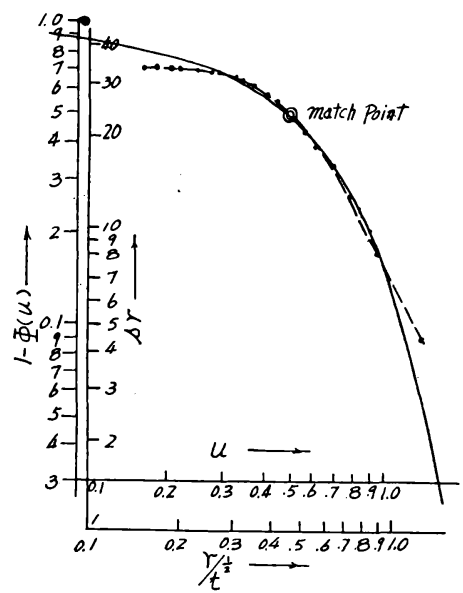

よる透水係数 $k=0.0527 \mathrm{~cm} / \mathrm{sec}$ の值汇近似している。

本実験に㧍いてガラス主管半径 $r_{0}=2.15 \mathrm{~cm}$ を用い根入れ $15 \mathrm{~cm}$ のとき非定常流透水試験を注水量を種々変え てなしていたが，時間の経過にしたがい 図一16 亿示すようと注水量 $Q=4.54 \mathrm{~cm}^{3} / \mathrm{sec}$ 亿して注水停止試験と注 水試験とをなしたときの $s \sim t$ 実測值と大なる開きを生ずるようになつた。この原因を調べたところ，使用した水 道水注鉄管の銹が非常に多く含まれ，これがガラス主管の底に沈澱していて，これを取りのぞいて実験をなしたと ころ，また図一6 のように両試験に怙ける $s \sim t$ 実測值にあまり開きが生じないようになつたので, 図一16 のよ ろになる原因は水道水の中の銹がガラス主管の底に沈溊したことによると考えられる。このことは実際のボーリ ング孔を利用するとき, 水の中の懸濁物が沈溊して蜂巣綿毛構造をボーリング底に形成しないように取りのぞかね. ばならないことを教えるものである。図一16の $s \sim t$ 実測值より直線解法で透水係数を求めると $k=0.0206 \mathrm{~cm} / \mathrm{sec}$ となり図一6 より求めたものより小となつている。

\section{図一16 ガラス主管内の水道水の銹の沈澱による注水試験と注水停止試験の} $\boldsymbol{s} \sim \boldsymbol{t}$ 実測值の開き

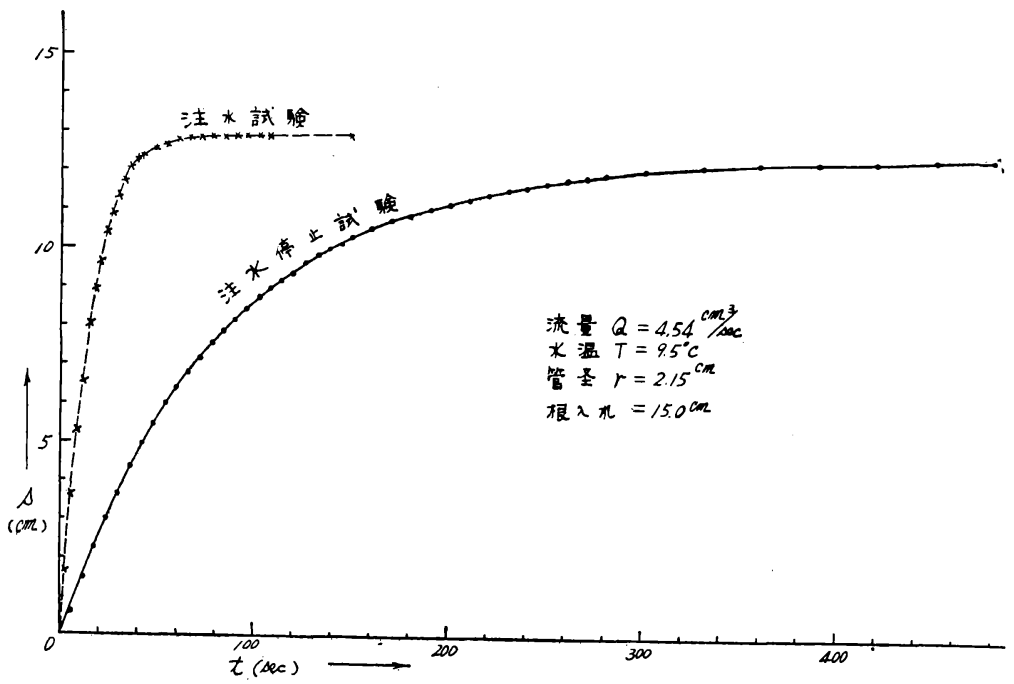

上述の非定常流透水試験により求めた透水係数を験証するためと, 図一3に示す定水頭透水実験装置にきりか兄 て砂表面より深さ $15 \mathrm{~cm}, 20 \mathrm{~cm}, 25 \mathrm{~cm}$ の点までピエゾ管を插入して各風の透水係数を測定した。このときの流 量を $Q\left(\mathrm{~cm}^{3} / \mathrm{sec}\right)$ ，砂凮の上下に抢ける水頭差を $H(\mathrm{~cm})$, 砂風の厚さを $L(\mathrm{~cm})$ とする。

砂の透水方向に直角な断面積は $A=2260 \mathrm{~cm}^{2}$ であつた。表一5 亿は $k=Q L / A H$ とよつて求めた透水係数と非 
定常流透水試験によつて求めた透水係数の值を示す。表一5 飞よれば非定常流透水試験による $k$ の值と定水頭透 水試験による $k$ の值は近似して括り上述の理論の罗当なることがわかる。

表一5

\begin{tabular}{|c|c|c|c|c|c|c|c|c|c|c|c|}
\hline \multirow{3}{*}{$\begin{array}{l}\text { 砂表面よ } \\
\text { )の深さ } \\
(\mathrm{cm})\end{array}$} & \multirow{3}{*}{$\underset{(\mathbf{c m})}{\boldsymbol{L}}$} & \multicolumn{9}{|c|}{ 定 水頭透 水試 匼 } & \multirow{3}{*}{$\begin{array}{c}\text { 韭定党流 } \\
\text { 試験 } \\
k(\mathrm{~cm} / \mathrm{sec})\end{array}$} \\
\hline & & \multicolumn{2}{|c|}{$Q=29.21 \mathrm{~cm}^{3} / \mathrm{sec}$} & \multicolumn{2}{|c|}{$Q=23.43 \mathrm{~cm}^{3} / \mathrm{sec}$} & \multicolumn{2}{|c|}{$Q=18.42 \mathrm{~cm}^{3} / \mathrm{sec}$} & \multicolumn{2}{|c|}{$Q=13.46 \mathrm{~cm}^{3} / \mathrm{sec}$} & \multirow{2}{*}{$\frac{k}{\text { 平均值 }}$} & \\
\hline & & $H(\mathrm{~cm})$ & $\mathrm{k}(\mathrm{cm} / \mathrm{sec})$ & $H(\mathrm{~cm})$ & $k(\mathrm{~cm} / \mathrm{sec})$ & $H(\mathrm{~cm})$ & $k(\mathrm{~cm} / \mathrm{sec})$ & $H(\mathrm{~cm})$ & $k(\mathrm{~cm}(\mathrm{sec})$ & & \\
\hline $15 \sim 20$ & 5 & 1.27 & 0.0508 & 1.04 & 0.0498 & 0.78 & 0.0530 & 0.52 & 0.0573 & 0.0527 & 0.0505 \\
\hline $20 \sim 25$ & 5 & 1.04 & 0.0621 & 0.78 & 0.0650 & 0.78 & 0.0530 & 0.44 & 0.0607 & 0.0602 & 0.0561 \\
\hline
\end{tabular}

次に（1）式を導くときに, 井戸底近傍の 帯水風中の等ポテンシャル面が半球形をなす としたが，これを確かめるために図一2に招 いてガラス主管の周辺にピエゾ管を 5 本放射 線上に種々の深さに挿入し, ガラス主管に注 水量 $Q=13.50 \mathrm{~cm}^{3} / \mathrm{sec}$ で水を注ぎ定常流状 態になつたとき, ガラス主管内の水頭は溢流 水面より $s_{0}=16 \mathrm{~cm}$ となり, このときのピ エゾ管の水頭をピエゾメータとて測定する。 ガラス主管の半径は $r_{0}=1.88 \mathrm{~cm}$ のものを用 い, 根入れは $20 \mathrm{~cm}$ とした。このときの水 頭の分布状態を図一17 と示す。ただしこの 図に拁いてガラス主管内の水頭 $s_{0}=16 \mathrm{~cm}$ を 1 としたときの各ピエゾ管の水頭の割合でポ テンシャルを示す。曲線に数字のあるのが等 ポテンシャル線を示す。この実験に㧊いて

$$
\begin{aligned}
k=\frac{Q}{2 \pi r_{0} s_{0}} & =\frac{13.50}{2 \times 3.14 \times 1.88 \times 16} \\
& =0.0715 \mathrm{~cm} / \mathrm{sec}
\end{aligned}
$$

となり, 非定常流透水試験のときの $k$ の值よ り大となつているが，これはピエゾ管挿入に よりガラス主管の底周辺の砂を多少ゆるめた 結果と考兄られ， $k=0.0715 \mathrm{~cm} / \mathrm{sec}$ を用いて

$$
\frac{s}{s_{0}}=\frac{Q}{2 \pi k r s_{0}}
$$

の式により，rを変化さして $s / s_{0}$ を求めた理論等ポテンシャル線を 図一17 亿点線で示す。これによつて実測值 と理諭值が比較的近似していることにより, 井戸底近傍の帯水風中の等ポテンシャル面が半球形をなすという仮 定が実用的にこいことが証明された。

上述の理論は laminar flow なることを前提とし て抢り,いままでの実験も laminar flow の状態とあ つたか否かを確かめねばならない。そこで図一2の 実験装置によつてガラス主管に注入する水量 $Q$ を少 量にして定常流状態になつたときのガラス主管の水 頭 $s_{0}$ を測定し, 段階的にQを増しそれぞれの場合 定常流状態の $s_{0}$ を測定し, $Q \sim s_{0}$ の関係を図示した ものが 図一18である。図示のようにこの関係はガ ラス主管半径 $r_{0}=2.15 \mathrm{~cm}, 1.88 \mathrm{~cm}$ それぞれの根 入れ $15 \mathrm{~cm}, 20 \mathrm{~cm}$ の二つの場合いづれも直線的で ある。 $\left.\mathrm{Jacob}^{4}\right)$ とよれば $B, C$ を常数として $s_{0}=B Q$ $+C Q^{2}$ の関係があるとしているが, この式の右辺の
図一17 ガラス主管半径 $r_{0}=1.88 \mathrm{~cm}$ ，根入れ $20 \mathrm{~cm}, Q=$ $13.50 \mathrm{~cm}^{3} / \mathrm{sec}$ で定常流状態のときの帯水層内の水頭 分布図, ただしガラス主管内の水頭を 1 としたときの 割合を示す

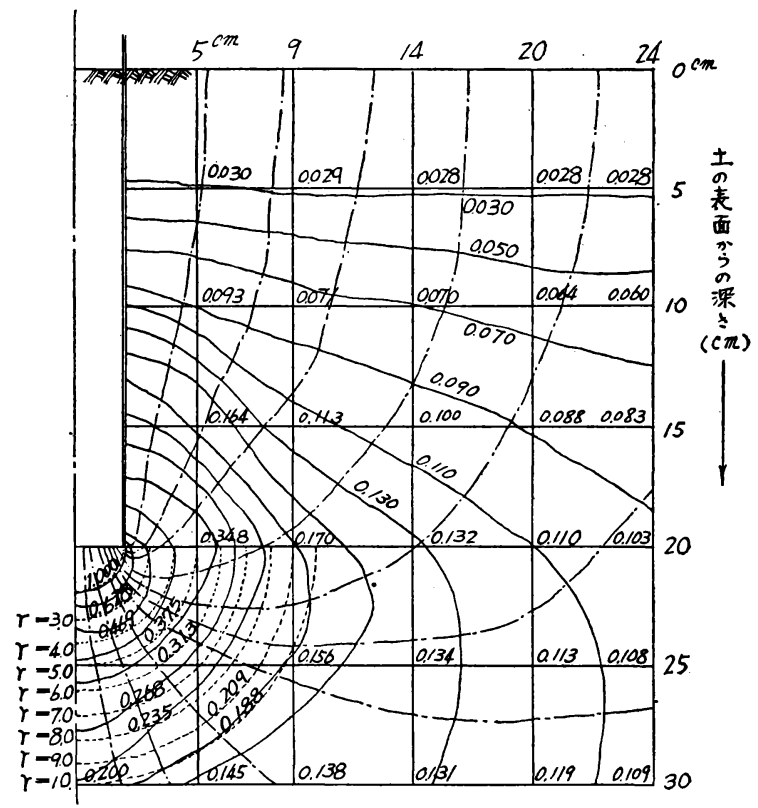

図一18 $s_{0} \sim Q$ の関係

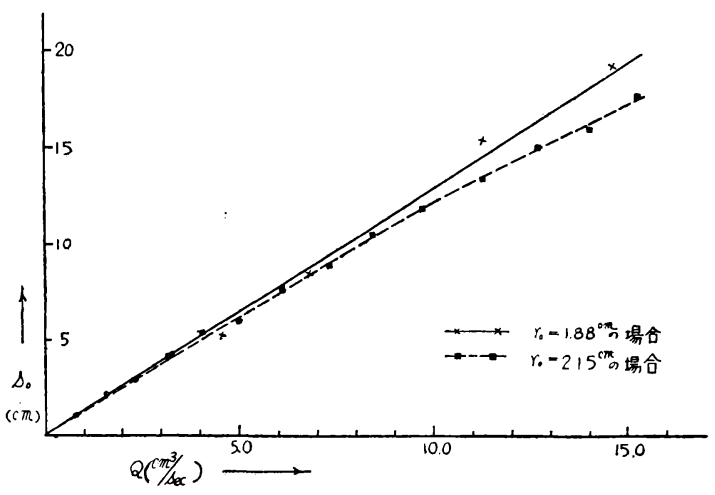


第二項は turbulent flow がある場合を示しているが, 図一18 は $s_{0}=B Q$ であることを示し，この実験に括いて はすべて laminar flow の状態にあることがいえる。図一18 亿示した試験は井戸の揚水試験に扔ける step-drawdown test を逆にしたもので段陼的注水武験と称することにする。

\section{7. 結 語}

透水性地盤上に堤防や土堰堤を造るとき，地盤の地質を調べたり，透水係数を知るためにボーリングをなすが， 透水係数測定のため砂質土，磷質土では不擤乱土を採取することが不可能で，現状のままで透水係数を測定で きればよいわけで，このためにボーリング孔にケーシング パイプを打込み，これに注水して定常流状態になるの をまつて測定し透水係数を求める方法があるが，この方法だけでなく非定常流透水試験法によつて 透水係数を求 めて験証するのも意義のあることである。

比較的透水性の砂, 砂利の地盤の場合は井戸の揚水試験に扔ける非平衡試験や回復法によつて 透水係数を求め るが，この逆としてはボーリング孔を利用せる非定常流透水試験法と扔いて 注水試験でも注水停止試験でも適用 できるが, 透水性の小なるシルト質の土質では注水試験の $s \sim t$ 実測值と注水停止試験の $s \sim t$ 実測值との開きが 大となるようである。井戸の揚水試験より透水係数を求める場合 水位回復法によつて計算するのと同じょうに, この場合は注水停止試験によるのがよいと考号れるが，これに関しては今後種々な土について実験研究するつ もりである。

\section{参考文 献}

1) C.E. Jacob : Effective Radius of Drawdown Test to Determine Artesian Well, Proc. A.S.C.E. Vol. 72 I 1946

2) R.H. Brown: Selected Procedures for Analyzing Aquifer Test Data, Jour. Amer. Water Works Association Vol. 45, No. 81953

3) 1) の論文の pp. $634(8 \mathrm{c})$ 式参照

4) M.I. Rorabaugh: Graphical and Theoretical Analysis of Stepdrawdown Test of Artesian Well, Proc. A.S.C.E. vol. 79, December, 1953, pp. 1-3. 